Journal of Applied Veterinary Sciences, 6 (1): 18 - 20 (2021).

ISSN: Online: 2090-3308, Print: 1687-4072

Journal homepage : https://javs.journals.ekb.eg

\title{
Comparative Study for The Treatment of Inactive Ovary in Local Iraqi Breed Cow by Using Massage Method of The Ovaries and GnRH
}

\author{
Elias K. Hussein ${ }^{1}$ and Mohammed Yaurb ${ }^{2}$ \\ ${ }^{1}$ Department of Surgery and Theriogenology, College of Veterinary Medicine, University of Mosul, Ninawa, Iraq. \\ ${ }^{2}$ Department of anatomy, College of Veterinary Medicine, University of Mosul, Ninawa, Iraq. \\ "Corresponding Author, Elias K. Hussein, E-mail: eliaskhudhr@uomosul.edu.iq
}

\begin{abstract}
This study was conducted on 40 cows suffering from inactive ovaries brought to the Teaching Veterinary clinic of College of Veterinary, University of Mosul. The inactive ovary was diagnosed in 40 cows depending on the case's date and general examination by rectal palpation to determine the ovarian size and the existence of certain ovarian structures and check the uterine horns and body. The animals were divided following the identification of the affected animals with inactive ovaries, into two groups, each group composed of 20 cows. The animals in the first group were treated with $\mathrm{GnRH}$ hormone at a dose of $0.5 \mathrm{mg}$. In contrast, animals in the second group were treated by the ovaries' manual massage method via rectal palpation. The study findings clarified that the estrous response ratio amounts to $50 \%$ in the first group and $60 \%$ in the second group. Statistically, there were no differences in response ratio between the two groups in relation to the response.
\end{abstract}

\author{
Original Article: \\ DOI:https://dx.doi.org/10.21608/javs.20 \\ 21.140074 \\ Received :21 November, 2020. \\ Accepted :28 December, 2020. \\ Published in January, 2021.
}

This is an open access article under the term of the Creative Commons Attribution 4.0 (CCBY) International License. To view a copy of this license, visit:

http://creativecommons.org/licenses/by/4.0/

Keywords: Inactive ovary, GnRH, massage method, rectal palpation, estrous.

J. Appl. Vet. Sci., 6(1): $18-20$.

\section{INTRODUCTION}

A complete absence of ovarian activity characterizes inactive ovaries or true anestrus. The ovaries are calm, smooth without any functional structures on board (surface) and small by rectum palpation or ultrasonography (Ribadu et al., 1994;Zulu et al., 2000; Abraham, 2017). Inactive ovaries cause large economic loss when post parturient period to the first estrous becomes long (Ahmed et al., 2010). Cows production depends especially on reproduction and its often measured by the number of births for each animal in a determined period (Monget and Monniaux, 1995).

One of the important causes of depression of natural ovarian activities is impairment release or insufficient hormonal production of GnRH to grow and follicular development or it might because of no ovarian response to GnRH (Noakes, 1996; Abraham, 2017), or hormonal imbalance between (LH) and (FSH) (Jainudeen and Hafez, 2000). Some factors also help inactive ovaries occurring like species, weather, management, nutrition insufficiency, especially lactation; it's one of the factors that cause true estrus (Singh, 2000; Abraham, 2017).

Inactive ovaries in lactation cows cause the increase of prolactin hormone, which depresses GnRH secretion (Arthur et al., 1989; Abraham, 2017). Many methods have been used for treating inactive ovaries, such as hormonal, like injecting GnRH and PMSG in pregnant mares (Mansoor et al., 2011), and progesterone hormone (Mohammed, 1999; Al-Nuaimi et al., 2020). The un hormonal methods represent by adding mineral salts, vitamin and manual massage method of the ovaries through rectum used as a method for treating inactive ovaries in cows (Mansoor $\boldsymbol{e t}$ al., 2011). Therefore this study is designed to aim to almanac and comparison between manual massage method of the ovaries and GnRH adding method as a treatment for inactive ovaries in local Iraqi cows.

\section{MATERIALS AND METHODS}

The study was conducted on 40 local cows suffering from true inactive ovaries brought to the veterinary teaching clinic, Veterinary College, Mosul University. These cows had at least one parturition 
three months ago. All cows were fed the same regular ration. The inactive ovary diagnosis was based on the case history and general examination of ovaries, uterine horns, uterine body and cervix by rectal palpation. Cows were divided into two groups. Each group consisted of twenty cows. The first group of cows was treated by injecting a single dose of $0.5 \mathrm{mg}$ of $\mathrm{GnRH}$ intramuscularly. The second group's cows were treated manually soft massage, about 4-5 times at the same time for both ovaries through rectal palpation.

\section{Statistical analysis}

Statistical analysis using the Fisher exact test was used to evaluate the response results to estrus treatment and appearance in cows suffering from inactive ovaries.

\section{RESULTS}

Results of the study showed that using GnRH in cows suffering from inactive ovary led to estrus appearance in 10 cows of 20 cows with a response rate of 50\% While the cows in the second group were treated manually by massage led to estrus appearance in 12 cows of 20 cows and response rate $60 \%$. There were no significant differences in ratio response of treatment between the two groups.

Table 1: appearing response of treated Iraqi cows suffering from inactive ovaries by two methods.

\begin{tabular}{|c|c|c|c|}
\hline $\begin{array}{c}\text { Therapeutic } \\
\text { groups }\end{array}$ & $\begin{array}{c}\text { No.of } \\
\text { treated } \\
\text { cows }\end{array}$ & $\begin{array}{c}\text { No. of } \\
\text { cows } \\
\text { responded } \\
\text { to } \\
\text { treatment }\end{array}$ & $\begin{array}{c}\% \text { of } \\
\text { response } \\
\text { to } \\
\text { treatment } \\
\text { and } \\
\text { appearance } \\
\text { of estrus }\end{array}$ \\
\hline $\begin{array}{c}\text { First group } \\
\text { GnRH }\end{array}$ & 20 & 10 & $50 \%^{\mathrm{a}}$ \\
\hline $\begin{array}{c}\text { Second } \\
\text { group } \\
\text { Ovary } \\
\text { massage }\end{array}$ & 20 & 12 & $60 \%^{\mathrm{a}}$ \\
\hline
\end{tabular}

a: means there is no significant difference at the same column

\section{DISCUSSION}

An inactive ovary results in high economic loss through a long period between two parturitions and the first estrous cycle (Ahmed et al., 2010). Production of cows depends largely on reproduction efficiency and this is often measured by the number of born for each animal in determined time (Monget and Monniaux, 1995). The results of our study showed that using a single dose of GnRH for the treatment of local cows suffering from inactive ovaries resulted in ratio response in estrous appearance (50\%), and this was in agreement with results reported by (Rahawy, 2003; Mansoor et al., 2011) who emphasized that injection of GnRH led to FSH and LH release which enhance the ovary activities by stimulating the growth of ovarian follicles (Noakes et al.,2008). While the cause of this method's negative results could be attributed to the lack of the response of the cranial lobe of the pituitary gland to GnRH (Ball and Peters, 2004).

Our current results, represented by estrous appearance $60 \%$ following the activation of the inactive ovary of cows in the second group by manual massage, were agreed with (Edwell et al., 2004; Rahawy, 2009). The manual massages increase the ovarian blood supply or stimulate the nervous system (Tischner et al.,1996) spontaneously. The mechanism of manual massage is not exactly known yet, as was referred by (Romaniuk, 1973), who thought that the response might be due to activation of some internal factors in the ovary..

\section{REFERENCES}

ABRAHAM, F. 2017. An Overview of Functional Causes of Infertility in Cows. Journal of Fertilization: In Vitro - IVF-Worldwide, Reproductive Medicine, Genetics \& Stem Cell Biology, 05(02). https://doi.org/10.4172/2375-4508.1000203.

AL-NUAIMI, A. J., ALI ALZAHID, A., AHMED HAMID ALRUBAYE, T., ABID, A. R., JAWAD, R. A., AL-KHAFAJI, N. M., AL-SABBAGH, J. K., \& HASSAN, M. S. 2020. Effect of Progesterone and GnRH treatment on non-functional ovaries in Holstein cows after calving in Babylon province. IOP Conference Series: Earth and Environmental Science, 553(1). https://doi.org/10.1088/1755-1315/553/1/ 012021

AHMED, W. M., EL-KHADRAWY, H. H., AMAL, R. A. H. \& AMER, H. A. 2010. Applied investigations on ovaries inactivity in buffaloes heifers. Inter. J. Acad. Res., 1 (2): 26-32.

ARTHUR, G.H., NOAKES D.E., PEARSON, H. 1989. Veterinary Reproduction and obstetrics 6th ed, Bailliece Tindall, London, England. pp : 350-382, 591-599.

BALL, P. J. H. \& PETERS, A. R. (2004). Reproduction in cattle. 3rd ed., Blackwell Publishing, USA.

EDWELL, SM., SLAWOMIR, Z., TOMASZ, J. 2004. Comparative study on the efficacy of hormonal and non-hormonal treatment methods in ovarian a function affected dairy cow. Bull Vet Inst Pulway, 48: 265-267.

JAINUDEEN, M.R. AND HAFEZ, E.S.E. 2000. In Reproduction in farm animals 7th Edition Hafes B. and Hafes. ESE.

MANSOOR, A. R., TAHA, M. M., AHMED, K. D. AND MAJEED A. F. 2011. Treatment of Inactive ovaries in dairy cows. Al-Anbar J. Vet. Sci. Vol.: 4 No. (1).

MOHAMMED, F. 1999. Clinical efficacy of GnRH analogue (buserelin) and Oestradiol benzoate 
treatment in anoestrus buffaloes. Indian $\mathrm{J}$ Animal Sci., 69: 310-312.

MONGET, P., MONNIAUX D. 1995. Growth factors and control of folliculogenesis. J Reprod Fertil., 49, 321333.

NOAKES, D. E.; PARKINSON, T. J. \& ENGLAND, G. C. W. 2008. Arthur's Veterinary Reproduction and Obstetrics, W. B. Saunders Co. Ltd.

NOAKES, D. H. 1996. Functional forms of infertility. In: Arthur, G. H., Noakes, D.E., Pearson, H. and Parkinson, T. J. (eds). Veterinary Reproduction and Obstetrics. London, Philadelphia, Toronto, Sydnes, Tokyo, W. B. Saunders Company Ltd., PP. 356-371.

RAHAWY, M. A. 2003. Applied study on anestrous in Buffalo, Iraqi.

RAHAWY, M. A. 2009. Treatment of anestrous in Buffalo cows by massaging the uterus and ovaries rectally. Iraqi J. of Vet. Sci., 23(1): 23-25.

ROMANIUK, J., 1973. Treatment of ovarian disfunction in cow. Medycyna Wet. 29:296-298.

RIBADU, A. Y., WARD, W. R., \& DOBSON, H. 1994. Comparative evaluation of ovarian structures in cattle by palpation per rectum, ultrasonography and plasma progesterone concentration. The Veterinary Record, 135(19), 452-457.

SINGH, J. 2000. The reproductive pattern and efficiency of female buffaloes. Animal Reproduction Sci. 60: 593604.

TISCHNER, M.JR., NIEZGODA, J., TISCHNER, M. 1996. Study of the effect of manual massage of ovaries on the reproductive activity of the mare. Theriogenology.45: 1457-1462.

ZULU, V. C., NAKAO, T., YAMADA, K., MORIYOSHI, M., NAKADA, K., SAWA MUKAI, Y. 2000. Clinical response of inactive ovaries in dairy cattle after PRID treatment.Journal of reproduction and development. 46 (6):415-422

\section{How to cite this article:}

Elias K. Hussein and Mohammed Yaurb, 2021. Comparative Study For The Treatment Of Inactive Ovary In Local Iraqi Breed Cow By Using Massage Method Of The Ovaries And GnRH. Journal of Applied Veterinary Sciences, 6(1): $18-20$.

DOI: https://dx.doi.org/10.21608/javs.2021.140074 